\title{
Komparácia vnútorného zat’aženia brankárov vo futbale v tréningovom procese
}

\section{A comparison of the internal load in soccer training process of goalkeepers}

\author{
Matej Babic, Miroslav Holienka \\ Univerzita Komenského v Bratislave, Fakulta telesnej výchovy a športu
}

\begin{abstract}
Abstrakt
Vnútorné zataženie brankárov $v$ tréningovom procese skúmame z pohladu dosiahnutých hodnôt srdcovej frekvencie. Chceli sme rozširit poznatky o vplyve rozdielnych metodických foriem na vnútorné zataženie brankárov vo futbale a tým podporit možnosti vylepšenia ich tréningového procesu. Predpokladali sme, že brankári budú dosahovat významne vyššie hodnoty srdcovej frekvencie počas prípravnej hry v hernom tréningu ako počas prípravného cvičenia v hernom nácviku. Sledovaný súbor tvorili šiesti brankári v kategórií mladšieho a staršieho dorastu (U16, U17, U19). Pomocou športtesterov POLAR PRO sme zistili vnútorné zataženie brankárov, ktoré sme spracovali kompatibilným softwarom POLAR Team². Následne sme získané údaje vyhodnotili Wilcoxonovým T-testom a Cohenovým r. Zistili sme významne rozdielne priemerné hodnoty srdcovej frekvencie v jednotlivých metodických formách $(T=0 ; p \leq 0.05 ; r=0.9)$, čím sme štatisticky aj vecne logicky potvrdili náš predpoklad.
\end{abstract}

Klúčové slova: futbal, brankár, vnútorné zat’aženie, srdcová frekvencia, športtester

\begin{abstract}
The main topic of our research was to determine the internal load of goalkeepers in the soccer training process. We focused on the analysis of the achieved heart rate values. In this way we wanted to extend the knowledge of the impact of the various methodical forms on the internal load on soccer goalkeepers, there by supporting the effort to improve the youth training process. We assumed the goalkeepers reached a significantly different level of heart rate in different methodical forms. Six goalkeeper's $\left(U 16, U 17\right.$, U19) internal load were analysed by POLAR Team ${ }^{2}$. To determine statistical significance, we used the Wilcoxon T-test and then we calculated Cohen $r$ (effect size). We found significantly different mean heart rate values in individual methodical forms $(T=0 ; p \leq 0.05 ; r=0.9)$.
\end{abstract}

Key words: soccer, goalkeeper, internal load, heart rate, sporttester

\section{ÚVOD}

Hráčska funkcia brankára je vel'mi špecifickou funkciou. Od ostatných hráčov v poli sa líši najmä možnostou chytania lopty do rúk a teda sú na ňu kladené aj iné požiadavky. Brankár má vo futbale významné postavenie, musí disponovat vysokým stupňom mentálnej spôsobilosti a zodpovednosti, ktoré vyplývajú z jeho hráčskej funkcie (Tarkovič 2000; Luxbacher 2002; Ajamil et al. 2018).

Aby mohol tréner brankárov plánovat tréningový proces, musí svojho brankára detailne poznat. Neustále vzdelávanie sa mládežníckych trénerov brankárov, čerpanie nových poznatkov, hladanie nových prístupov a pokus o optimálne plánovanie a riadenie špecializovaného tréningového procesu je predpokladom pre úspešnú prípravu mladého brankára na futbal budúcnosti (Thissen 2001; Ruiz 2003; Smith 2004; Smith 2005). 
Vývojové tendencie vo futbale a rešpektovanie jednotlivých senzitívnych období sú nevyhnutné pri stavbe športového tréningu brankára (Hrnčiarik 2012; Peráček et al. 2017). Podla Barryho (2009) musí byt tréning jednoznačne zameraný na požiadavky zápasu, pretože práve ten určuje ciele a obsah jednotlivých súčastí športového tréningu. Gustafsson a Janson (1997) tvrdia, že najefektívnejším spôsobom prípravy brankára je špecializovaný tréning. Podobnou problematikou sa zaoberal aj Montesano (2016), ktorý zistil signfikantne výraznejšie zlepšenie u brankárov so špecializovaným tréningom oproti brankárom bez takého tréningu.

Postupom času je výrazne cítit potrebu nových (moderných) technológií, progresívnych programov a netradičných prístupov aj v tréningu brankára (Meurer 2001; Stőber 2001). Či je to využitie športtesterov v tréningu (aj v zápase) na sledovanie vnútorného zat’aženia alebo čoraz dôležitejšia integrácia tréningu brankára s družstvom, napr. súčinnost pri zakladaní útoku s obrannou formáciou alebo riešenie štandardných herných situácií.

Nároky na hru brankára sa nezvyšujú iba v obrannej fáze, ale hlavne v útočnej fáze. Môžeme konštatovat', že až 75 \% herných činností brankára je útočných (Smith 2004; Szwarc 2010). Preto si dovolíme tvrdit, že d’alšou $\mathrm{z}$ vývojových tendencií $\mathrm{v}$ hre brankára je zvýšenie počtu herných situácií, v ktorých musí hrat nohou, s čím úzko súvisí zakladanie útoku. Zakladanie útoku po prerušenej hre (kop od brány, priamy vol'ný kop) alebo neprerušenej hre (napríklad herná situácia „malá domov“) si vyžaduje od brankára vysokú úroveň technickej, ale aj taktickej pripravenosti.

$\mathrm{V}$ priebehu tréningového procesu dochádza k sumácií jednotlivých tréningových podnetov, ktorými pôsobíme na organizmus hráča. Ked' sa podnety dávkujú tak, že majú tréningový účinok (efekt), čiže prispievajú k rozvoju, resp. udržaniu stavu trénovanosti, hovoríme o tréningovom zatłažení. Podla vel'kosti tréningového zat’ǎenia dochádza v organizme hráča postupne k zmenám, čím sa postupne prispôsobuje zvyšujúcim dávkam zataženia (Holienka a Lednický 2000).

Srdcová frekvencia (SF) je všeobecne uznávaný a široko používaný objektívny fyziologický ukazovatel' pohybovej aktivity hráča $\mathrm{v}$ tréningovom procese, prípadne podl'a možností aj $\mathrm{v}$ zápase (Holienka 2016).

Rozdelenie srdcovej frekvencie do tréningových zón má zásadný význam pre riadenie športovej prípravy, jej individualizáciu, efektívnost’ a účinnost’ dosahovania určeného ciela (Olšák 1997).

Vencel (2013) počas zápasu mladšieho dorastu zistil, rozdielnu srdcovú frekvenciu brankára. Maximálna srdcová frekvencia v zápase vystúpila na 181 úderov/minútu a priemerná srdcová frekvencia bola 143 úderov/minútu. V d’alšom zápase zistil priemerné hodnoty srdcovej frekvencie u brankára iba 128 úderov/minútu.

Podl'a Peráčka et al. (2004) uplatňovanie metodických foriem v didaktickom procese vel'mi úzko súvisí s vonkajším zat’ǎením hráča (konkrétne s jedným jeho komponentom - zložitostoou), ale aj vnútorným zatažením. Metodické formy predstavujú rôzne formy usporiadania vonkajších podmienok a obsahu didaktického procesu umožňujúce plnit úlohy spojené s nácvikom a zdokonal'ovaním herných činností.

Peráček et. al (2004) d’alej uvádzajú, že v podmienkach prípravných cvičení, kde sú relatívne nemenné a izolované podmienky od hry, nacvičujeme technickú stránku herných činností jednotlivca (brankára). Dbáme pritom na všetky parametre hernej činnosti, napríklad na rôzne spôsoby chytania $\mathrm{v}$ stoji, chytania v páde, riešení situácie 1:1 alebo zakladania útoku. Prípravné cvičenia sa vykonávajú bez prítomnosti súpera, čiže aktívneho odporu hráča.

V prípravných hrách sa zameriavame na zdokonal'ovanie a stabilizáciu herných činností, ich technickej a taktickej stránky, ako aj na rozvoj tvorivého potenciálu hráča (brankára). Protirečivá činnost' súpera núti hráčov (brankárov) rýchlo prepínat z útočných činností na obranné, čím sa rozvijajú ich aktuálne univerzálne schopnosti (Peráček et al. 2004).

Podl’a Holienku (1998) vhodným obmeňovaním pravidiel a obsahovej náplne prípravných hier, ako jednej z metodických foriem plníme akcentované tréningové ciele a úlohy. 
Prípravné hry sú asociované s efektivitou tréningového procesu na herný výkon hráča (Clemente et al. 2012; Michailidis 2013; Benkovský et al. 2016). Pakusza a Tarkovič (2002) vo svojej práci uvádzajú, že prípravné hry svojou variabilitou, rôznorodostou a situačnou neočakávanostou vytvárajú ideálne podmienky pre komplexný rozvoj hernej spôsobilosti. Na základe vlastných poznatkov z hráčskej a trénerskej činnosti to môžeme potvrdit aj o hráčskej funkcii brankára.

\section{METODIKA}

V realizovanom výskume sme chceli rozšírit poznatky o funkčných odozvách organizmu futbalových brankárov $v$ jednotlivých súčastiach tréningového procesu, hernom nácviku a hernom tréningu. Na porovnanie intenzity vnútorného zataženia sme uplatnili prierezový ex post facto výskum.

Predpokladáme, že brankári budú dosahovat významne vyššie hodnoty srdcovej frekvencie počas prípravnej hry v hernom tréningu ako počas prípravného cvičenia $v$ hernom nácviku. Prípravné cvičenie na nácvik a prípravnú hru na zdokonal'ovanie sme vybrali z jednotlivých cvičení a hier, ktoré bežne používame $\mathrm{v}$ tréningovej praxi. V prípravnom cvičení sa zameriavame na technické zvládnutie vykonania brankárskeho zákroku, v prípravnej hre sa zameriavame na komplexné zdokonalenie brankárskeho zákroku v podmienkach hry (zápasu).

\section{Prípravné cvičenie (PC)}

Počet brankárov: 6

Zameranie: nácvik riešenia hernej situácie 1:1

Popis cvičenia: Brankári vo dvojiciach na stanovištiach (A, B, C) nacvičujú riešenie hernej situácie $1: 1$. Po každom opakovaní cvičenia si úlohy menia. Výmena dvojíc na jednotlivých stanovištiach nasleduje po 6'. Tréner vstupuje do cvičenia a koriguje správnost brankárskeho zákroku.

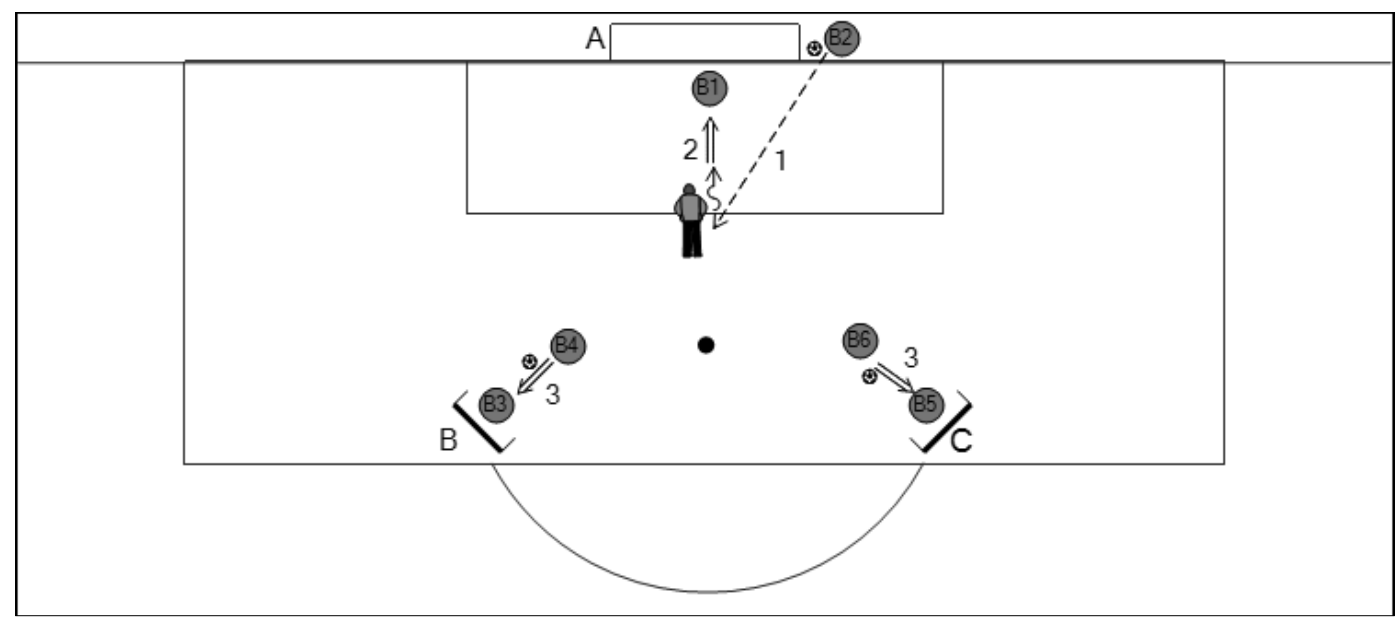

Obr. 1 Prípravné cvičenie 


\section{Prípravná hra (PH)}

Počet brankárov: $3: 3$

Interval zataženia (IZ): 2'

Počet opakovaní (PO): 5
Vel'kost' ihriska: $22 \times 18 \mathrm{~m}$

Interval odpočinku (IO): 2'

Počet sérií (PS): 1

Zameranie: zdokonal'ovanie riešenia hernej situácie $1: 1$, hry nohou a chytania $\mathrm{v}$ páde

Popis a pravidlá hry: Brankári hrajú vo vymedzenom priestore na vol’ný počet dotykov. Na celej vlastnej polovici ihriska môžu chytat loptu rukou (v obrannej fáze). Gól platí iba zo súperovej polovice ihriska. Ak sa lopta dostane za autovú čiaru, autové vhadzovanie sa vykonáva nohou. Ak sa lopta dostane za bránkovú čiaru a má nasledovat rohový kop, loptu má družstvo, ktoré mala mat rohový kop a začína od vlastnej brány.

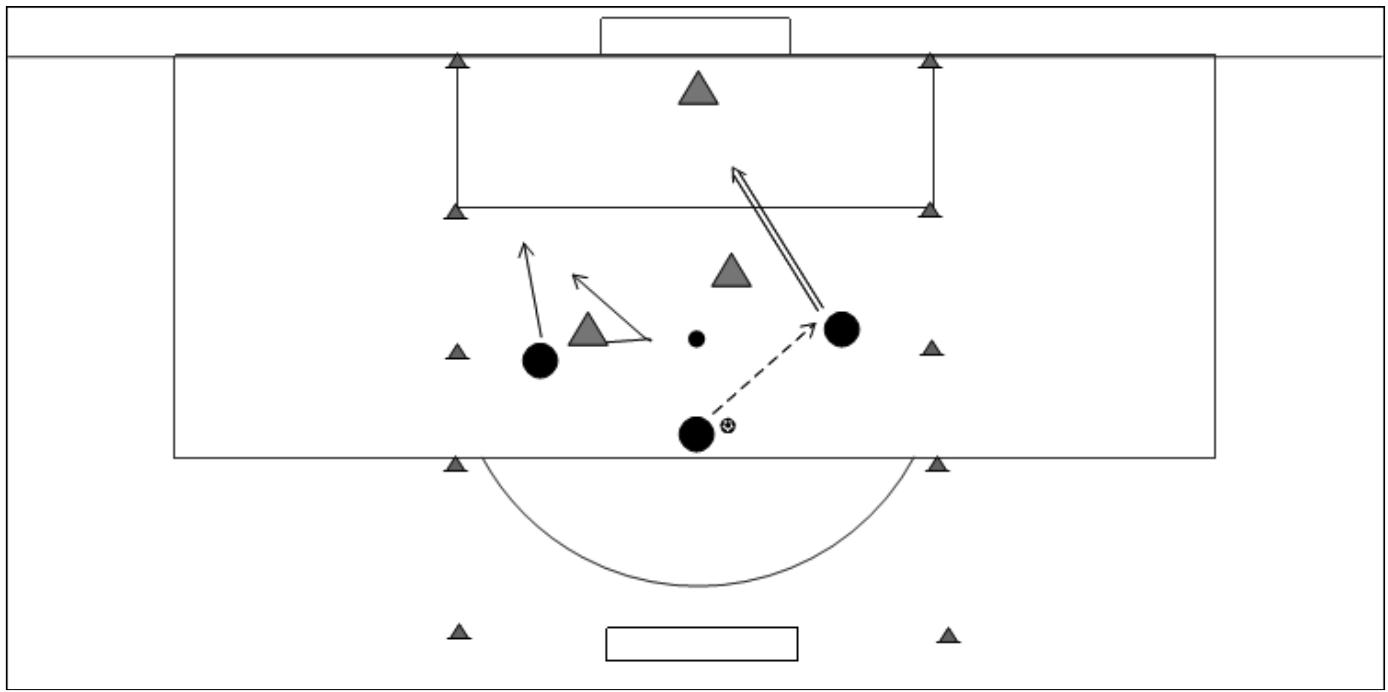

Obr. 2 Prípravná hra

Zo stanoveného ciel’a vyplynuli nasledujúce úlohy:

1. Zistił funkčné odozvy organizmu brankárov na zataženie v prípravnom cvičení a v prípravnej hre pomocou športtesterov.

2. Vyhodnotit a porovnat získané výsledky z vnútorného zataženia brankárov na základe fyziologických kriviek.

Výskumný súbor tvorili šiesti brankári družstva ŠK Slovan Bratislava v kategórii do 16, do 17 a do 19 rokov. Brankári sú členmi družstiev, ktoré sú účastníkmi slovenskej celoštátnej 1. ligy staršieho a mladšieho dorastu. Vekový priemer sledovaných brankárov bol v čase výskumu 16,5 \pm 0,6 roku. Klub ŠK Slovan Bratislava disponuje štatútom Futbalovej akadémie. Tréningový proces brankárov predstavuje 5-6 tréningových jednotiek týždenne.

Hlavnou metódou získavania výskumných údajov bolo meranie srdcovej frekvencie sledovaných brankárov pomocou športtesterov. Na meranie boli použité športtesteri značky POLAR Team².

Maximálna srdcová frekvencia brankárov bola zistená testom podl’a Hippa (2007). V teste ide o opakované bežecké úseky tak, aby zo základného pomalého poklusu postupne narastala rýchlost' až $\mathrm{k}$ individuálnej maximálnej intenzite. 
Test obsahuje beh na šírku ihriska:

- beh nízkej intenzity (na rozbehanie) 6krát,

- beh strednej intenzity $6 \mathrm{krát}$,

- beh submaximálnej intenzity $6 \mathrm{krát}$

- beh maximálnej (subjektívnej) intenzity 1 krát.

Na základe zistených maximálnych srdcových frekvencií sme určili pomocou programu POLAR Team $^{2}$ pre každého brankára zóny tréningového zataženia. Tieto zóny a ich rozdelenie významne ovplyvňujú riadenie, individualizáciu a efektívnost tréningového procesu.

Tab. 1: Základné charakteristiky sledovaných brankárov a ich a zóny tréningového zat’aženia

\begin{tabular}{|c|c|c|c|c|c|c|}
\hline Meno & $\mathbf{B}_{1}$ & $\mathbf{B}_{2}$ & $\mathbf{B}_{3}$ & $\mathrm{~B}_{4}$ & $\mathbf{B}_{5}$ & $B_{6}$ \\
\hline Vek & 17,3 & 17,1 & 16,8 & 16,4 & 16,0 & 15,6 \\
\hline Telesná výška (m) & 187,0 & 187,6 & 191,7 & 186,8 & 189,6 & 175,0 \\
\hline Telesná hmotnost’ [kg] & 83,0 & 80,1 & 84,0 & 91,4 & 77,6 & 63,0 \\
\hline $\mathbf{S F}_{\max }\left[\right.$ úderov.min $\left.{ }^{-1}\right]$ & 197 & 201 & 198 & 198 & 205 & 200 \\
\hline $100-90 \%$ & $197-177$ & $201-181$ & $198-178$ & $198-178$ & $205-185$ & $200-180$ \\
\hline $89-80 \%$ & $176-157$ & $180-161$ & $177-158$ & $177-158$ & $184-164$ & $179-160$ \\
\hline $79-70 \%$ & $156-137$ & $160-141$ & $157-138$ & $157-138$ & $163-144$ & $159-140$ \\
\hline $69-60 \%$ & $136-117$ & $140-121$ & $137-118$ & $137-118$ & $143-123$ & $139-120$ \\
\hline $59-50 \%$ & $116-97$ & $120-101$ & $117-98$ & $117-98$ & $122-103$ & $119-100$ \\
\hline
\end{tabular}

Na spracovanie a vyhodnotenie získaných údajov sme použili výpočet percentuálneho a časového zastúpenia hodnôt srdcovej frekvencie $\mathrm{v}$ jednotlivých zónach pomocou špeciálneho programu POLAR Team ${ }^{2}$.

Na zistenie štatistickej významnosti sme využili Wilcoxonov T-test a následne sme vypočítali Cohenovo $\mathrm{r}$ (effect size). Zvolená hladina štatistickej významnosti bola $\mathrm{p} \leq 0.05$.

Získané výsledky sme porovnávali, zistovali medzi nimi súvislosti a na ich základe sme formulovali odporúčania pre tréningovú prax.

\section{VÝSLEDKY}

V predkladanom príspevku sledujeme funkčné odozvy organizmu na vybrané prípravné cvičenie a prípravnú hru. V obidvoch metodických formách boli sledovaní všetci šiesti brankári.

\section{Funkčné odozvy organizmu brankárov v prípravnom cvičení}

Interval srdcovej frekvencie (SF) u brankárov v prípravnom cvičení (PC) bol od 85 úderov/min. do 159 úderov/minútu. Najnižšiu hodnotu $\mathrm{SF}$ počas $\mathrm{PC}$ sme zaznamenali u brankára $\mathrm{B}_{5}$ a $\mathrm{B}_{4}$ ( 85 úderov/min.), u ktorého sme zaznamenali aj najvyššiu hodnotu SF počas PC (159 úderov/ min.). Priemerná hodnota SF bola $130 \pm 5$ úderov/min. a priemerná hodnota maximálnej srdcovej frekvencie počas PC bola $149 \pm 8$ úderov/minútu. 
Tab. 2: Hodnoty srdcových frekvencií u brankárov v prípravnom cvičení a jednotlivé zóny tréningového zat’aženia

\begin{tabular}{|c|c|c|c|c|c|c|c|c|c|c|c|}
\hline \multicolumn{12}{|c|}{ Training Session Report } \\
\hline \multirow[t]{2}{*}{$\mathrm{PC}$} & & \multirow{2}{*}{6} & \multicolumn{3}{|c|}{ HR } & \multicolumn{5}{|c|}{ Time in sportzones } & \multirow{2}{*}{$\begin{array}{c}\text { Above } \\
\text { threshold }\end{array}$} \\
\hline & & & Minimum & Average & Maximum & $50-59$ & $60-69$ & $70-79$ & $80-89$ & $90-100$ & \\
\hline \multirow{2}{*}{$\begin{array}{c}\text { B1 } \\
\text { Max HR: } 197\end{array}$} & \multirow[t]{2}{*}{ 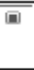 } & \multirow[t]{2}{*}{$00: 20: 00$} & 99 & 122 & 136 & $00: 06: 21$ & $00: 13: 39$ & $00: 00: 03$ & $00: 00: 00$ & $00: 00: 00$ & $00: 00: 00$ \\
\hline & & & $50,0 \%$ & $61,0 \%$ & $69,0 \%$ & $31,8 \%$ & $68,0 \%$ & $0,2 \%$ & $0,0 \%$ & $0,0 \%$ & $0,0 \%$ \\
\hline \multirow{2}{*}{$\underset{\text { Max HR: } 201}{ }$} & \multirow[t]{2}{*}{ (1) } & \multirow[t]{2}{*}{$00: 20: 00$} & 89 & 127 & 143 & $00: 11: 35$ & $00: 07: 21$ & 00:01:04 & 00:00:00 & $00: 00: 00$ & $00: 00: 00$ \\
\hline & & & $44,0 \%$ & $63,0 \%$ & $71,0 \%$ & $57,9 \%$ & $36,8 \%$ & $5,3 \%$ & $0,0 \%$ & $0,0 \%$ & $0,0 \%$ \\
\hline \multirow{2}{*}{ Max HR: 198} & \multirow[t]{2}{*}{$\bar{\square}$} & \multirow[t]{2}{*}{$00: 20: 00$} & 108 & 134 & 155 & $00: 07: 35$ & $00: 06: 05$ & $00: 06: 20$ & $00: 00: 00$ & $00: 00: 00$ & $00: 00: 00$ \\
\hline & & & $54,0 \%$ & $67,0 \%$ & $78,0 \%$ & $37,9 \%$ & $30,4 \%$ & $31,7 \%$ & $0,0 \%$ & $0,0 \%$ & $0,0 \%$ \\
\hline \multirow{2}{*}{$\begin{array}{c}\text { B4 } \\
\text { Max HR: } 198\end{array}$} & \multirow[t]{2}{*}{$\bar{\square}$} & \multirow[t]{2}{*}{$00: 20: 00$} & 85 & 133 & 159 & $00: 03: 49$ & $00: 08: 47$ & $00: 07: 14$ & $00: 00: 10$ & $00: 00: 00$ & $00: 00: 00$ \\
\hline & & & $42,0 \%$ & $67,0 \%$ & $80,0 \%$ & $19,1 \%$ & $43,9 \%$ & $36,2 \%$ & $0,8 \%$ & $0,0 \%$ & $0,0 \%$ \\
\hline \multirow{2}{*}{$\begin{array}{c}\text { B5 } \\
\text { Max HR: } 205\end{array}$} & \multirow[t]{2}{*}{ m } & \multirow[t]{2}{*}{$00: 20: 00$} & 85 & 125 & 155 & $00: 08: 42$ & 00:09:18 & $00: 02: 00$ & $00: 00: 00$ & $00: 00: 00$ & $00: 00: 00$ \\
\hline & & & $41,0 \%$ & $61,0 \%$ & $76,0 \%$ & $43,5 \%$ & $46,5 \%$ & $10,0 \%$ & $0,0 \%$ & $0,0 \%$ & $0,0 \%$ \\
\hline \multirow{2}{*}{$\begin{array}{c}\text { B6 } \\
\text { Max HR: } 200\end{array}$} & \multirow[t]{2}{*}{$\overline{0}$} & \multirow[t]{2}{*}{$00: 20: 00$} & 113 & 137 & 148 & $00: 09: 40$ & $00: 05: 59$ & $00: 04: 21$ & $00: 00: 00$ & $00: 00: 00$ & $00: 00: 00$ \\
\hline & & & $56,0 \%$ & $68,0 \%$ & $74,0 \%$ & $48,3 \%$ & $29,9 \%$ & $21,8 \%$ & $0,0 \%$ & $0,0 \%$ & $0,0 \%$ \\
\hline
\end{tabular}

$\mathrm{Z}$ pohl'adu časového zotrvania $\mathrm{v}$ jednotlivých zónach tréningového zat̉aženia, brankári sa v priemere najviac pohybovali v zóne $60-69 \% \mathrm{SF}_{\max }-8,52 \pm 2,58 \mathrm{~min}$. $(42,6 \%)$ a zóne $50-59 \%$ $\mathrm{SF}_{\max }-7,97 \pm 2,47$ min. $\left(39,8 \%\right.$ ). $\mathrm{V}$ zóne $70-79 \% \mathrm{SF}_{\max }$ sa najviac pohybovali brankári $\mathrm{B}_{4}$ (7,23 min. - 36,2\%) a $\mathrm{B}_{3}\left(6,33\right.$ min. - 31,7 \%). Do zóny $80-89 \% \mathrm{SF}_{\max }$ sa dostal iba brankár $\mathrm{B}_{4}$ na 0,17 min. $(0,8 \%)$ a do zóny $90-100 \% \mathrm{SF}_{\max }$ sa nedostal žiaden zo sledovaných brankárov.

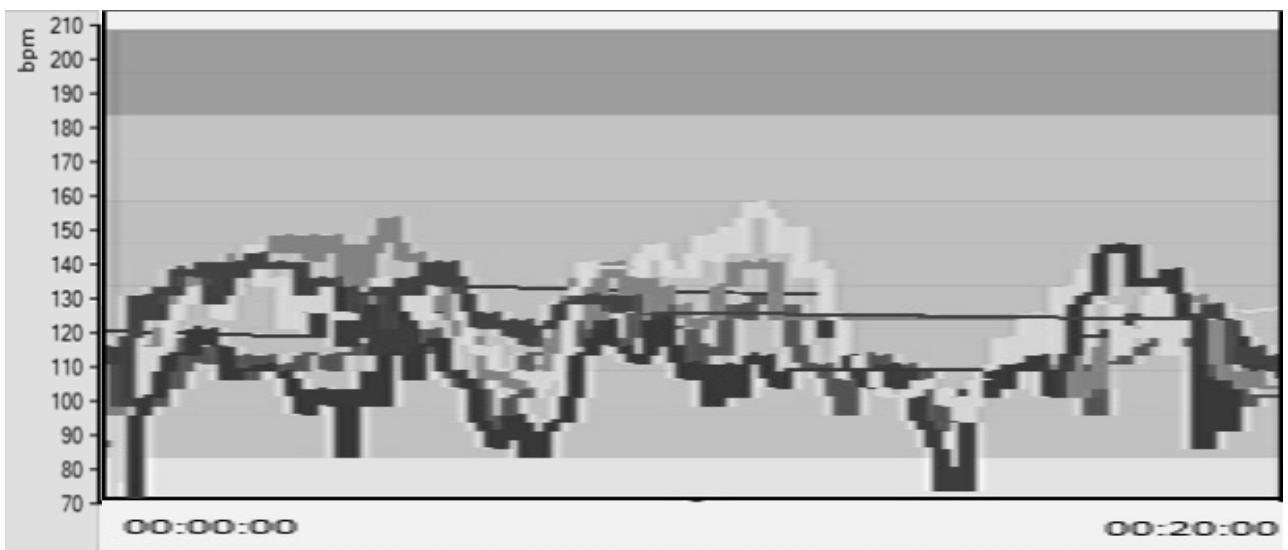

Obr. 3 Fyziologické krivky brankárov v prípravnom cvičení

\section{Funkčné odozvy organizmu brankárov v prípravnej hre}

Interval srdcovej frekvencie u brankárov v prípravnej hre (PH) bol od 92 úderov/min. do 205 úderov/minútu. Najnižšiu hodnotu SF počas $\mathrm{PH}$ sme zaznamenali u brankára $\mathrm{B}_{2}$ ( 92 úderov/min.) a najvyššiu hodnotu SF počas PH sme zaznamenali u brankára B. CH. (205 úderov/min.). Priemerná hodnota SF bola $156 \pm 9$ úderov/min. a priemerná hodnota maximálnej srdcovej frekvencie počas $\mathrm{PH}$ bola $186 \pm 11$ úderov/minútu. 
Tab. 3: Hodnoty srdcových frekvencií u brankárov v prípravnej hre a jednotlivé zóny tréningového zat’aženia

\begin{tabular}{|c|c|c|c|c|c|c|c|c|c|c|c|}
\hline \multicolumn{12}{|c|}{ Training Session Report } \\
\hline \multirow[t]{2}{*}{$\mathrm{PH}$} & & \multirow{2}{*}{0} & \multicolumn{3}{|c|}{ HR } & \multicolumn{5}{|c|}{ Time in sport zones } & \multirow{2}{*}{$\begin{array}{c}\text { Above } \\
\text { threshold }\end{array}$} \\
\hline & & & Minimum & Average & Maximum & $50-59$ & $60-69$ & $70-79$ & $80-89$ & $90-100$ & \\
\hline \multirow{2}{*}{$\begin{array}{l}\text { B1 } \\
\text { Max HR: } 197\end{array}$} & \multirow[t]{2}{*}{$\bar{\square}$} & \multirow[t]{2}{*}{ 00:20:00 } & 111 & 146 & 171 & 00:01:09 & $00: 06: 13$ & $00: 04: 39$ & $00: 07: 58$ & 00:00:01 & $00: 00: 03$ \\
\hline & & & $56,0 \%$ & $74,0 \%$ & $86,0 \%$ & $5,7 \%$ & $31,1 \%$ & $23,3 \%$ & $39,8 \%$ & $0,1 \%$ & $0,3 \%$ \\
\hline \multirow{2}{*}{$\underset{\text { Max HR: } 201}{\text { B2 }}$} & \multirow[t]{2}{*}{$\bar{\square}$} & \multirow[t]{2}{*}{$00: 20: 00$} & 92 & 152 & 186 & $00: 01: 41$ & $00: 03: 59$ & $00: 04: 52$ & $00: 06: 49$ & 00:02:39 & $00: 03: 55$ \\
\hline & & & $46,0 \%$ & $77,0 \%$ & $94,0 \%$ & $8,5 \%$ & $19,9 \%$ & $24,3 \%$ & $34,0 \%$ & $13,3 \%$ & $19,6 \%$ \\
\hline \multirow{2}{*}{$\begin{array}{c}\text { B3 } \\
\text { Max HR: } 198 \\
\end{array}$} & \multirow[t]{2}{*}{$\overline{0}$} & \multirow[t]{2}{*}{$00: 20: 00$} & 117 & 157 & 181 & $00: 00: 28$ & $00: 04: 14$ & 00:04:19 & 00:08:37 & $00: 02: 22$ & $00: 04: 23$ \\
\hline & & & $59,0 \%$ & $79,0 \%$ & $91,0 \%$ & $2,4 \%$ & $21,2 \%$ & $21,6 \%$ & $43,0 \%$ & $11,8 \%$ & $22,0 \%$ \\
\hline \multirow{2}{*}{$\begin{array}{c}\text { B4 } \\
\text { Max HR: } 198\end{array}$} & \multirow[t]{2}{*}{$\bar{\square}$} & \multirow[t]{2}{*}{$00: 20: 00$} & 103 & 150 & 181 & $00: 02: 28$ & $00: 04: 08$ & $00: 03: 57$ & $00: 08: 14$ & $00: 01: 13$ & $00: 02: 37$ \\
\hline & & & $52,0 \%$ & $75,0 \%$ & $91,0 \%$ & $12,3 \%$ & $20,7 \%$ & $19,8 \%$ & $41,1 \%$ & $6,1 \%$ & $13,1 \%$ \\
\hline \multirow{2}{*}{$\begin{array}{c}\text { B5 } \\
\text { Max HR: } 205\end{array}$} & \multirow[t]{2}{*}{$\bar{\square}$} & \multirow[t]{2}{*}{$00: 20: 00$} & 117 & 174 & 205 & $00: 00: 08$ & $00: 01: 55$ & $00: 04: 58$ & $00: 02: 45$ & $00: 10: 14$ & $00: 10: 32$ \\
\hline & & & $57,0 \%$ & $85,0 \%$ & $100,0 \%$ & $0,7 \%$ & $9,6 \%$ & $24,8 \%$ & $13,8 \%$ & $51,1 \%$ & $52,6 \%$ \\
\hline \multirow{2}{*}{$\begin{array}{c}\text { B6 } \\
\text { Max HR: } 200\end{array}$} & \multirow[t]{2}{*}{$\overline{0}$} & \multirow[t]{2}{*}{$00: 20: 00$} & 100 & 159 & 193 & $00: 01: 26$ & $00: 01: 56$ & $00: 06: 27$ & $00: 04: 02$ & 00:06:09 & $00: 06: 47$ \\
\hline & & & $50,0 \%$ & $79,0 \%$ & $96,0 \%$ & $7,2 \%$ & $9,7 \%$ & $32,2 \%$ & $20,2 \%$ & $30,7 \%$ & $33,9 \%$ \\
\hline
\end{tabular}

$\mathrm{Z}$ pohl'adu časového zotrvania $\mathrm{v}$ jednotlivých zónach tréningového zataženia, brankári sa v priemere najviac pohybovali v zóne $80-89 \% \mathrm{SF}_{\max }-6,38 \pm 2,2 \mathrm{~min} .(31,9 \%)$. V zóne $90-100 \% \mathrm{SF}_{\max } \mathrm{sa}$ brankári pohybovali v priemere 3,78 $\pm 3,43 \mathrm{~min}$. (18,9\%) a nad úrovňou anaeróbneho prahu (ANP) v priemere 4,72 $\pm 3,28$ min. (23,6 \%). V zóne $90-100 \% \mathrm{SF}_{\max }(10,23 \mathrm{~min} .-51,1 \%)$ a nad úrovňou ANP (10,53 min. - 52,6\%) sa najviac pohyboval brankár $\mathrm{B}_{5}$, ktorý dosiahol v tejto PH aj svoju maximálnu SF (205 úderov/min.).

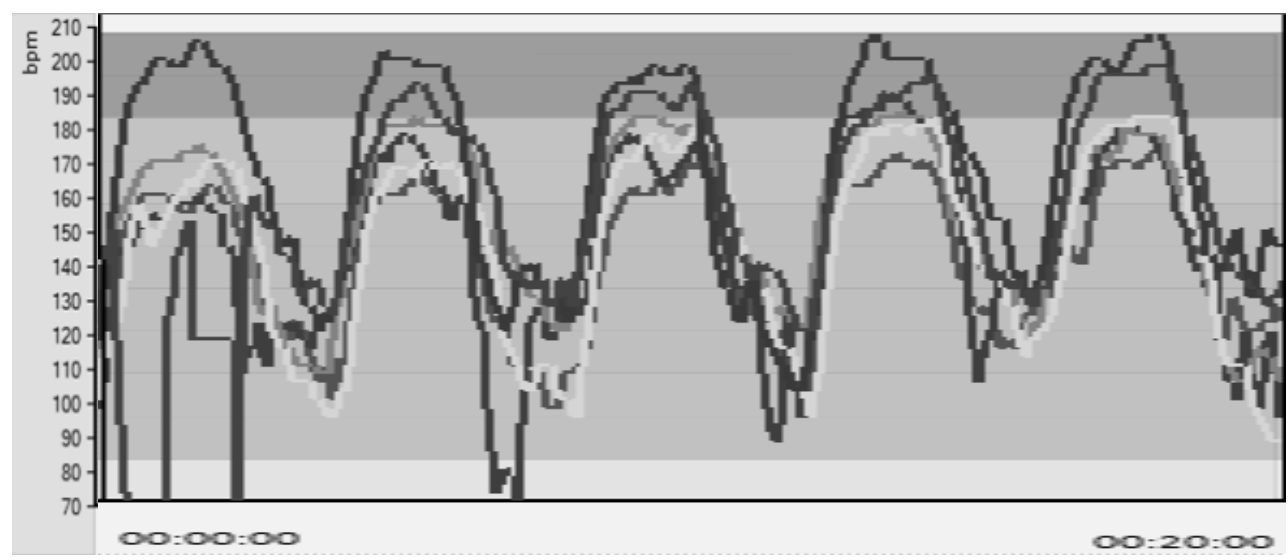

Obr. 4 Fyziologické krivky brankárov v prípravnej hre

Porovnanie funkčných odoziev organizmu v prípravnom cvičení a prípravnej hre

Zistené hodnoty srdcovej frekvencie brankárov v prípravnom cvičení a v prípravnej hre sme vzájomne porovnali.

U všetkých brankárov sme namerali vyššie priemerné aj maximálne srdcové frekvencie počas prípravnej hry ako počas prípravného cvičenia. Najvyšší rozdiel v hodnotách priemernej SF sme zistili u brankára $\mathrm{B}_{5}$ (49 úderov/min.), naopak najnižší rozdiel u brankára $\mathrm{B}_{4}$ (17 úderov/min.). Najvyšší rozdiel v hodnotách maximálnej SF sme zistili taktiež u brankára B. CH. (50 úderov/ min.), najnižší rozdiel opät u brankára $\mathrm{B}_{4}$ (22 úderov/min.).

Priemerný rozdiel v hodnotách priemernej SF v PC a PH bol $27 \pm 10$ úderov/min., a priemerný rozdiel v hodnotách maximálnej SF bol $37 \pm 10$ úderov/minútu. 
V PC dosahovali brankári hodnoty srdcovej frekvencie v priemere $130 \pm 5$ úderov/min. a v PH hodnoty v priemere $156 \pm 9$ úderov/minútu. Na základe zistených rozdielnych SF sme Wilcoxonovým T-testom potvrdili štatistickú významnost’ $(T=0 ; p \leq 0.05 ; r=0.9)$. Následne sme vypočítali Cohenovo r (effect size). Tým sme potvrdili predpoklad o významne vyššej SF v PH ako v PC aj vecne logicky s vel'kým účinkom.

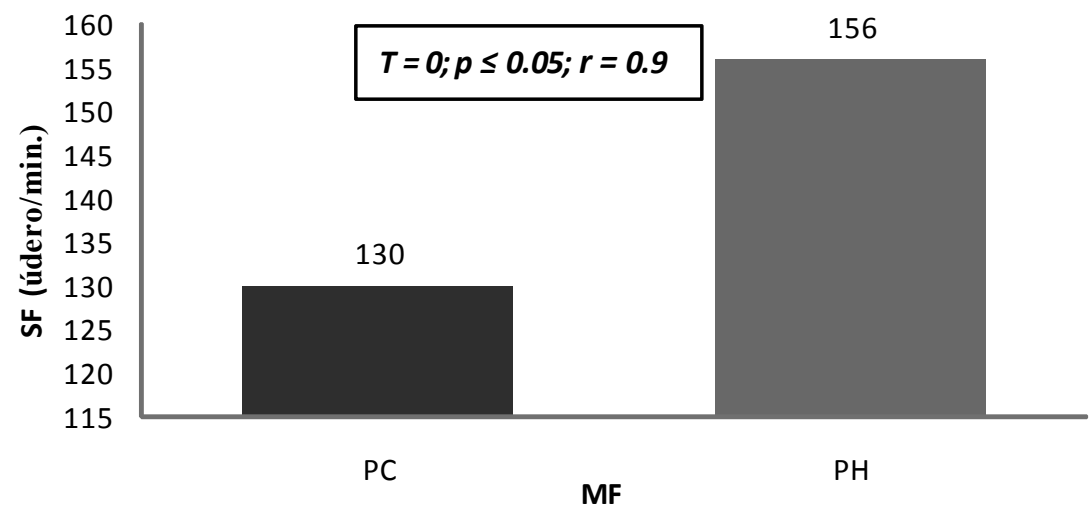

Obr. 5 Priemerné hodnoty srdcovej frekvencie brankárov v prípravnom cvičení a v prípravnej hre

\section{DISKUSIA}

Zámerom výskumného sledovania bolo zistit, porovnat a rozšírit poznatky o funkčných odozvách organizmu brankárov na navrhnuté prípravné cvičenie a prípravnú hru. Predpokladali sme, že brankári budú dosahovat významne vyššie hodnoty srdcovej frekvencie počas prípravnej hry $\mathrm{v}$ hernom tréningu ako počas prípravného cvičenia $\mathrm{v}$ hernom nácviku.

Predpoklad sme dokázali potvrdit štatisticky významne pomocou Wilcoxonovho T-testu na 5\% hladine štatistickej významnosti $(\mathrm{T}=0 ; \mathrm{p} \leq 0.05)$. Následne sme vypočítali Cohenovo $\mathrm{r}$ (effect size), kde vyšlo $r=0,9$ (vel'ký účinok) a predpoklad sme potvrdili aj vecne logicky.

Počas prípravného cvičenia sa brankári pohybovali prevažne v prvých dvoch zónach tréningového zataženia, čo znamená dominantne zameranie sa na rozvoj zručnostného potenciálu.

Brankári mohli izolovane od podmienok zápasu nacvičovat vybrané herné činnosti bez akéhokolvvek časového, či priestorového tlaku. Potvrdzujú to aj nami namerané maximálne a priemerné hodnoty SF.

Na rozdiel od prípravného cvičenia, môžeme konštatovat že prípravná hra vyvolala adekvátne adaptačné zmeny okrem zručnostného potenciálu aj na rozvoj zdatnostného potenciálu. Zaznamenali sme v nej vyššie maximálne aj priemerné hodnoty SF a aj väčšie časové a percentuálne zastúpenie $\mathrm{v}$ jednotlivých zónach, ktoré znamenajú vyvolanie požadovaných adaptačných zmien $\mathrm{v}$ organizme brankárov ako počas prípravného cvičenia.

Zvolené intervaly załaženia a intervaly odpočinku v PH boli zvolené správne, ked’že hodnoty srdcovej frekvencie u hráčov počas intervalu odpočinku klesali na úroveň 120 až 130 úderov/min., resp. 130 až 140 úderov/min.

V intervale odpočinku sa srdcová frekvencia nevracala do východiskovej úrovne. $Z$ hl'adiska adaptačných procesov je takto stanovený interval odpočinku chápaný ako predížený podnet pre srdcovo-cievny a dýchací systém (Sedláček et al. 2007).

V práci sme použili intervalovú metódu, ktorá je vhodná pre rozvoj zdatnostného potenciálu. Rovnaké intervaly zataženia a odpočinku použili aj Babic, Holienka a Mikulič (2018), ktorý ich 
zvolili v trvaní 2 minúty a taktiež počas intervalu odpočinku klesli hodnoty srdcovej frekvencie rovnako na úroveň 120 až 130 úderov/min., resp. 130 až 140 úderov/minútu.

Holienka (2004) sledoval vnútorné zataženie hráčov na rôzne prípravné hry a zistil, že počas intervalov odpočinku klesli hodnoty srdcovej frekvencie na 120 až 125 úderov/min., čím boli vytvorené vhodné podmienky pre d’alšie opakovanie tréningových podnetov.

Na základe týchto poznatkov súhlasíme s názorom Hrnčiarika (2012), že už v etape športovej prípravy mládeže vo futbale je potrebné venovat sa rozvoju pohybových schopností a herných zručností v podmienkach pravidelného brankárskeho tréningu. Brankári by mali nacvičovat a zdokonal'ovat technickú stránku obranných a útočných herných činností v žiackych a v dorasteneckých kategóriách v podmienkach, ktoré sú charakteristické časovým a priestorovým tlakom (zápasové podmienky) a pod vplyvom únavy.

\section{ZÁVER}

Sledovanie funkčných odoziev organizmu futbalových brankárov vo fáze nácviku a zdokonal'ovania herných činností môže výrazne pomôct' trénerom v d’alšom plánovaní, optimalizácií a evidencii tréningového procesu. Rozšírit poznatky o tejto problematike sme chceli najmä z dôvodu, že v slovenskom futbale sa menej využívajú moderné technológie na rozdiel od futbalu vo svete. Mnoho klubov na Slovensku nemá potrebné finančné prostriedky na zabezpečenie moderných technológií pre progresívne vedenie tréningového procesu mládežníckych brankárov.

Náš predpoklad a zistené výsledky sme potvrdili štatisticky aj vecne logicky a na ich základe odporúčame v tréningovej praxi:

- realizovat špecializovanú prípravu tréningového procesu brankára vychádzajúcu z vývojových tendencií hry brankára,

- monitorovat a vyhodnocovat intenzitu vnútorného zataženia brankárov pomocou športtesterov počas celého tréningového procesu,

- pri zostavovaní prípravných cvičení a prípravných hier v plánovaní tréningového procesu brankára upravovat vonkajšie podmienky (zložitost', organizácia, pravidlá) tak, aby spíňali požiadavky danej vekovej kategórie a požiadavky zápasu.

\section{Reference}

Ajamil, D. L. et al., (2018). Analysis of the effectiveness of Under-16 football goalkeepers. In: Apunts. Educació Física i Esports. 131, 60-79. ISSN 02148757.

Babic, M., Holienka, M. \& Mikulič, M., (2018). Internal load of soccer goalkeepers during the improvement of selected game activities. In: Journal of Physical Education and Sport. 18(3), 1731-1737. ISSN 2247-8051.

Barry, B., (2009). Winning Goalkeeper Training. Madrid: Reedswain. ISBN 15-91-641-144.

Benkovský, L. et al., (2016). Efektívnost' športovej prípravy mladších žiakov vo futbale. In: Studia Sportiva. 10(1), 117-128. ISSN 1802-7679.

Clemente, F. et al., (2012). The usefulness of small-sided games on soccer training. In: Journal of Physical Education and Sport. 12(1), 93-102. ISSN 2247-806X.

Gustafsson, R. \& Janson, L., (1997). Secrets of Soccer. Göteborg: Optimaltryck.

Hipp, M., (2007). Futbal: Rozvoj vybraných pohybových schopností, diagnostika a strečing v družstve vrcholového futbalu. Bratislava: SPN. ISBN 978-80-10-01146-9.

Holienka, M., (1998). Tréningové zat’aženie a interval odpočinku, základné kategórie herného tréningu vo futbale. In: Acta Facultatis Educationis Physicae Universitatis Comenianae. 34, 147-150. ISSN 0520-7371.

Holienka, M., (2004). Fyziologické odozvy organizmu hráča vo futbale na zataženie v prípravnej hre s malým počtom hráčov. In: Zborník vedeckých prác katedry športových hier FTVŠ UK č.1. Bratislava: Občianske združenie Športové hry, s. 14-19. ISBN 80-88901-97-9.

Holienka, M., 2016. Internal load of soccer players during preparatory games with a medium number of players. In: Journal of Physical Education and Sport. 16(2), 546-550. ISSN 2247-806X. 
Holienka, M. \& Lednický, A., (2000). Funkčné odozvy organizmu hráča vo futbale na zataženie v rôznych prípravných hrách. In: Optimalizácia zat’aženia v telesnej a športovej výchove. Bratislava: STU, s. 46-50. ISBN 80-227-1336-8.

Hrnčiarik, P., (2012). Vplyv špecifických tréningových podnetov na individuálny herný výkon juniorského brankára vo futbale. Bratislava. Dizertačná práca. Univerzita Komenského v Bratislave, Fakulta telesnej výchovy a športu, Katedra športových hier.

Luxbacher, J., (2002). The soccer goalkeeper - techniques, tactics, training. Leeds: Leisure press. ISBN 0-7360-4180-X.

Meurer, M., (2001). Nachwuchsarbeit ist in ständiger Prozess. In: BDFL Journal. 23(2), 18-19. ISSN 1101-1084.

Michailidis, Y., (2013). Small sided games in soccer training. In: Journal of Physical Education and Sport. 13(3), 392-399. ISSN 2247-806X.

Montesano, P., (2016). Goalkeeper in soccer: performance and explosive strength. In: Journal of Physical Education and Sport, 16(1), 230-233. ISSN 2247-806X.

Olšák, S., (1997). Srdce - zdravie - šport: Využitie sledovania srdcovej frekvencie v športe a pri pohybovej aktivite pre zdokonalenie aktívneho zdravia. Moravany nad Váhom: Raval. ISBN 80-967850-8-7.

Pakusza, Z. \& Tarkovič, Š., (2002). Prípravné hry v hernom tréningu mladých futbalistov. In: Optimalizácia zataženia v telesnej $a$ športovej výchove. Bratislava: STU, s. 9.

Peráček, P. et al., (2004). Teória a didaktika športových hier. Bratislava: FTVŠ UK. ISBN 80-89197-00-0.

Peráček, P. et al., (2017). Selected indicators of an individual game performance of goalkeeper at the European Championship among the 17-year-old elite soccer players. In: Journal of Physical Education and Sport. 17(1), 188-193. ISSN 2247-806X.

Ruiz, L., (2003). About the The Spanish Goalkeeping Bible. Madrid: Reedswain Publishing. ISBN 1591640237.

Sedláček, J. et al., (2007). Kondičná atletická príprava a rekreačná atletika. Bratislava. ISBN 978-80-223-2288-1.

Smith, S., (2004). Goalkeeping for soccer. Leeds: Coachwise Ltd. ISBN 1-902523-66-0.

Smith, S., (2005). Goalkeeping practices. Leeds: Coachwise Ltd. ISBN 1-876554-54-1.

Szwarc, A. et al., (2010). The efficiency model of goalkeeper's actions in soccer. In: Baltic Journal of Health and Physical Activity. 2(2), 132-138. ISSN 20801297.

Stöber, B., (2001). Jugendarbeit ist immer perspektivische Arbeit. In: BDFL Journal. 23(2), 9. ISSN 1101-1084.

Tarkovič, Š., (2000). Analýza hry brankára. In: P. PERÁČEK et al.,: Majstrovstvá Európy do 21 rokov na Slovensku. Bratislava: Slovenský futbalový zväz, s. 41-49.

Thissen, G., (2001). Torwartschule für Kinder und Jugendfussballer. Berlin: Sportverlag. ISBN 3-927570-06-0.

Vencel, A., (2013). Tréner brankárov. Bratislava: ITEM, spol. s.r.o. ISBN 978-80-971447-7-7.

\section{Korespondující autor:}

Mgr. Matej Babic

matej.babic@uniba.sk

+421918038633 